\title{
Miejsce postpamięci w edukacji międzykulturowej ${ }^{1}$
}

\section{The Place of Post-memory in Intercultural Education}

Summary: The article is an attempt to describe the book The Lesson of (Un)presence. PolishJewish heritage in Polish language education by Agnieszka Kania. The book deals with the place of the subject matter related to the Holocaust in Polish language classes and the ways of educating about the past. The researcher suggests that the school discourse that concerns postmemory should not only take into account the sensitivity of the modern student, but first and foremost, utilise the post-memory narratives to describe the phenomena that currently have to be addressed. Owing to such an approach, the school gets the opportunity for creating conditions for authentic dialogue with the past and, on the basis of this - for the reflection upon the contemporary world. If the education about the Holocaust serves such a purpose, it becomes one of the pillars of intercultural education.

Key words: post-memory, intercultural education, Polish-Jewish heritage, Polish language education

Termin „postpamięć” po raz pierwszy użyty przez Marianne Hirsch² jest dziś odmieniany przez wszystkie przypadki. Jego obecność w kontekście edukacji zmusza do przemyślenia formuły pedagogiki Zagłady obejmującej kolejne pokolenia, dla których Holokaust jest i będzie coraz bardziej odległym Wydarzeniem. W konsekwencji historia edukacji o Zagładzie wybrzmiewa kakofonią wielu narracji przeszłości z różnym powodzeniem adaptowanych do wrażliwo-

${ }^{1}$ W artykule omawiam publikację Agnieszki Kani. Zob. A. Kania: Lekcja (nie)obecności. Dziedzictwo polsko-żydowskie w edukacji polonistycznej. Kraków 2017, s. 212.

${ }^{2}$ M. Pakier: „Postmemory” jako figura w popularnym dyskursie o Zagładzie. „Kwartalnik Historii Żydów” 2005, nr 2, s. 195-208; M. Hirsch: Family Frames: Photography, Narrative and Postmemory. Cambridge 2000. 
ści i potrzeb uczniów oraz młodych czytelników. Uwzględniając zmienność form nauczania o trudnej przeszłości, można przyjąć, że postpamięć jest

interpretacją opowiadanych zdarzeń, kulturową reprezentacją przybierającą kształt tu i teraz ${ }^{3}$.

Pierwsze próby nauczania o Zagładzie przypadają na lata sześćdziesiąte $\mathrm{XX}$ wieku. Zostały zainspirowane wyemitowanym w izraelskim radiu wykładem pod znaczącym tytułem Wychowanie po Auschwitz wygłoszonym przez Theodora W. Adorna. Główna teza zaproponowana przez filozofa dotyczyła celu nauczania o Zagładzie, które powinno mieć charakter prewencyjny. Tak rozumiana pedagogika wykluczała obawę przed powtórzeniem się Wydarzenia. Gwarancją tej pewności miała być formuła Adornowskiej edukacji, u której podstaw znalazła się empatia ${ }^{4}$.

Wydaje się, że we współczesnej edukacji empatia nadal zajmuje centralne miejsce, choć przecież metodyka nauczania o Holokauście zdążyła wypracować mechanizmy pozwalające na wyjście z poziomu emocjonalnego w kierunku intelektualnego uogólnienia oraz w konsekwencji — wiedzy historycznej. Istnienie tych trzech poziomów oraz podejmowanie działań dydaktycznych zmierzających od emocji przez zrozumienie aż do osadzenia wydarzeń w kontekście historycznym pozwala na bezpieczne, nietraumatyzujące nauczanie o Zagładzie.

Warto zauważyć, że obecnie edukacji o Zagładzie, oprócz oczywistego nauczania o Wydarzeniu, przypisuje się wciąż nowe zadania. Im więcej czasu upływa od momentu historycznego, w którym się rozegrała, tym częściej wpisuje się ją w dyskursy odległe od pierwotnych założeń pedagogicznych. Bogusław Śliwerski przekonuje, że pedagogika w ponowoczesności unieważnia tradycyjne pytanie: „Przy pomocy jakich metod i ku jakim celom musimy dzisiaj wychowywać?”, i w jego miejsce formułuje nowe: „Jaką społeczną funkcję spełnia jeszcze dzisiaj wychowanie?"5.

Zatem współczesna edukacja o Holokauście nie ogranicza się jedynie do wyzwalania empatii czy zdobywania wiedzy o przeszłości, ale zostaje wpisana w nowoczesny projekt, mający u podstaw koncepcję wychowania międzykulturowego czy wielokulturowego. Pierwsza z nich, włączając edukację o Zagładzie w model kształcenia społeczeństwa do życia w warunkach kulturowego zróżnicowania, opiera się na procesie międzykulturowego uczenia się podczas kon-

${ }^{3}$ A. Boroń: Holokaust i jego reprezentacje w przestrzeni pamięci i tożsamości. W: Eadem: Pedagogika (p)o Holocauście. Pamięć. Tożsamość. Edukacja. Poznań 2013, s. 93.

${ }^{4}$ Zob. R. Szuchta: Refleksje o nauczaniu historii Holokaustu w polskiej szkole. W: Tematy żydowskie. Red. E. Traba, R. Traba. Olsztyn 1999.

${ }^{5}$ B. Śliwerski: Współczesne teorie i nurty wychowania. Kraków 2010, s. 363. 
taktu z Innym. Druga, przy równoczesnej gwarancji zabezpieczenia pamięci o Zagładzie, przywołuje inne narracje wymagające objęcia pamięcią kulturową. Taki model edukacji przygotowuje do elastyczności myślenia oraz wychowania do autentycznego i głębokiego przeżycia spotkania z Innym. Zmiana w edukacyjnym podejściu do Holokaustu wymaga jednak akceptacji wielokierunkowego modelu pamięci, który uwzględniałby i legitymizowałby wielkość obowiązujących narracji bez wskazywania tej jednej - dominującej.

Dlatego tak ważne wydają się publikacje dotyczące pedagogiki Zagłady, poddające przeszłość wszechstronnemu oglądowi uwzględniającemu przede wszystkim perspektywę współczesności. Z pewnością należy do nich książka Agnieszki Kani Lekcja (nie)obecności. Dziedzictwo polsko-żydowskie w edukacji polonistycznej, wyrastająca z doświadczeń autorki kierującej polsko-izraelskim projektem w Centrum Badań Edukacyjnych i Kształcenia Ustawicznego na Wydziale Polonistyki Uniwersytetu Jagiellońskiego. Warto dodać, że badaczka przez kilkanaście lat pracowała w liceum ogólnokształcącym i ma na swoim koncie współautorstwo podręczników Czarowanie słowem, natomiast w 2015 roku opublikowała książkę ,Polak młody” na lekcjach języka polskiego. Edukacja polonistyczna a kształtowanie poczucia tożsamości narodowej. Trudno nie dostrzec, że recenzowana publikacja Kani jest efektem odbytej przez nią długoletniej szkolnej praktyki, a w kontekście haseł międzykulturowości oraz wielokulturowości również rozbudowanym komentarzem na temat kształtowania tożsamości uczniów dołączonym po dwóch latach do książki „Polak mtody"...

Według autorki lekcja dotycząca Innego nadal nie została przez polską szkołę dostatecznie odrobiona, a przecież zaangażowanie w jej realizację zwiększa szansę na mądrą, bo krytyczną i pełną empatii edukację młodych ludzi. Prawdopodobnie tytuł książki odzwierciedla nie tylko migotliwość podjętych do tej pory działań, ale również niepewny status pamięci związanej z polsko-żydowskim dziedzictwem. Taka interpretacja tytułu może kierować ku refleksji o tożsamości rozumianej jako nieustanny trud definiowania oraz ustalania bądź znoszenia granic. Znakomicie o nieprzerwanym ruchu towarzyszącym budowaniu tożsamości pisze Aleksandra Kunce, odmawiając mu ciągłości, systemowości, porządku oraz zajmowania centrum. Według badaczki ów ruch przypomina raczej kłącze, sytuuje na marginesach i odbywa się w kontekście zmienności, odmienności oraz astrukturalności. Stąd wymaga on od nas zgody na porzucanie i negowanie tego, co dotąd wydawało się niezbywalne oraz trwałe:

Jesteśmy beznadziejnie kulturowi, zakorzenieni w małych kulturach, w swych małych roszczeniach, we własnych praktykach moralnych (które nierzadko traktuje się jako absolutne), czyli pieczołowicie wznoszonym 
i potwierdzanym kulturowo locum. $\mathrm{Z}$ drugiej strony to locum nieustannie jest dyslokowane ${ }^{6}$.

Wydaje się, że Kania doskonale „czuje” fenomen dyslokacji. Czyni z niej podstawę tworzonego przez siebie alfabetu edukacji międzykulturowej. Szczególnie interesujący jest fakt, że swoista metodyka spotkań z Innym została zainspirowana działaniami Sharon Azarii, która w 2016 roku prowadziła na Uniwersytecie Jagiellońskim dwa seminaria dotyczące izraelskiej wizji antysemityzmu. Dostrzeżone różnice w formułowaniu tego zjawiska sygnalizowały potrzebę przemyślenia edukacji o Zagładzie zarówno w polskiej, jak i izraelskiej szkole. Odejście od pewników mocujących edukację w stałych i znanych przestrzeniach skłoniło do refleksji na temat wydawałoby się już przepracowanych problemów. O znaczeniu ruchu myśli w kontekście tożsamości pisał Zygmunt Bauman:

[...] „odkrywamy” tożsamość, gdy nie jest już dana, lecz zadana. Gdy trzeba ją dopiero posiasść, gdy nie da się jej posiąść raz na zawsze, ale trzeba ją brać w posiadanie wciąż na nowo, za każdym razem wybierając z innego zestawu możliwości, o jakim wiadomo, że będzie się zmieniał, ale nie wiadomo w jakim kierunku?

Autorka Lekcji (nie)obecności... nie dość, że uznaje płynność ponowoczesnej edukacji międzykulturowej, to jeszcze inspiruje się metodyką, która znakomicie sprawdziła się w zupełnie innych warunkach — w szkole izraelskiej. Nie oznacza to jednak, że zaproponowana przez nią narracja jest kalką żydowskiego dyskursu o Zagładzie. Przeciwnie — autorka świadoma specyfiki polskiej edukacji wybiera i rozbudowuje szczególnie te działania, które mogą okazać się przydatne w rodzimym kontekście; inspiruje się nimi.

W pierwszym rozdziale Od tożsamości ,narodowej" do kulturowej autorka dokonuje przeglądu pojęcia „edukacja kulturowa” i przygląda się, w jaki sposób była ona i jest realizowana w szkole, zaznaczając przy tym, że bez względu na zmiany zachodzące $\mathrm{w}$ paradygmacie tego rodzaju edukacji, edukatorem kulturowym pozostaje nauczyciel polonista. Autorka przyznaje, że również i jego świadomość (nie tylko uczniów) podlega zmianom, a poczucie tożsamości narodowej, które reprezentuje, może ulegać zmianie. Badaczka chętnie cytuje wypowiedź Andrzeja Borowskiego na temat edukacji polonistycznej i szcze-

${ }^{6}$ A. Kunce: Zlokalizować tożsamość!. W: Dylematy wielokulturowości. Red. W. Kalaga. Kraków 2004, s. 80.

${ }^{7}$ Z. Bauman: O tarapatach tożsamości w ciasnym świecie. W: Dylematy wielokulturowości..., s. 29. 
gólnie wyraźnie zwraca uwagę na taki jej model, który pozwala w nauczaniu dostrzegać

proces jeszcze bardziej złożony i wydłużony w czasie, ale właściwie permanentny, zainicjowany zapewne przez szkołę, ale kontynuowany indywidualnie, wzbogacany samodzielnie własnymi lekturami, przemyśleniami czy rozmowami [...] motywowany ciekawością, pragnieniem poznania człowieka i świata, wreszcie tak czy inaczej formułowanym poszukiwaniem sensu życia ${ }^{8}$.

$\mathrm{W}$ procesie tym niezwykle istotne wydają się detale, a jego powodzenie w dużej mierze wynika z ich uważnego oglądu. Autorka przyznaje się do tego, że jeden $\mathrm{z}$ takich detali stał się zaczynem zmian, jakie miały się dokonać w jej pojmowaniu tożsamości, a zarazem zapowiedzią innego podejścia do edukacji międzykulturowej zaproponowanej uczniom. Otóż badaczka poddała krytycznej refleksji logotyp towarzyszący międzynarodowemu seminarium Centropa Summer Academy. Przedstawiał on orła z polskiego godła połączonego z żydowską menorą. Przepołowiony symbol wydał się wtedy nadużyciem i wzbudził mieszane uczucia tak nauczycielki, jak i uczniów. Wyzwaniem, jak przyznaje Kania, w myśleniu o tej graficznej hybrydzie, któremu ona sama musiała stawić czoła, była zgoda na „podzielenie się Polską jako ojczyzną” (s. 45).

Uświadomienie sobie takiej oczywistości, że w Polsce istniała kiedyś „duża grupa narodowa, która także myślała o Polsce jako o swojej ojczyźnie” (s. 46), otworzyło autorkę na nowe doświadczenia związane z wielo- i międzykulturowością, osadzoną przede wszystkim w kontekście współczesnego kryzysu migracyjnego. Nie dziwi więc fakt, że konstatacji zawierającej w sobie formułę ojczyzny, którą trzeba podzielić się z potrzebującymi, towarzyszy „lista” książek adresowanych do niedorosłych czytelników9. Ich lektura według badaczki jest dobrym punktem wyjścia do szkolnej refleksji na temat migracji oraz uchodźców ${ }^{10}$.

${ }^{8}$ A. Borowski: Tożsamość polska i wielokulturowość jako problem edukacji polonistycznej. W: Polonistyka w przebudowie. T. 2. Red. M. Czermińska, S. Gajda, K. Kłosiński et al. Kraków 2005, s. 173.

9 Por. B. Gromadzka: Edukacja polonistyczna w kontekście dylematów kulturowych. W: Edukacja. Migracja. Edukacja międzykulturowa w kontekście kryzysu migracyjnego z perspektywy krajów V4. Red. E. Kledzik, M. Praczyk. Poznań 2016, s. 99-114.

${ }^{10}$ Richard Pring przekonuje, że współczesne migracje nie są niczym nowym w historii świata, a strach przed tym zjawiskiem oswajano dzięki edukacji: „W przeszłości zdarzały się wielkie migracje, a wówczas szkoły pomagały młodym ludziom pokonać uprzedzenia, uszanować tradycje i uczyły życia w pokoju ku ogólnemu pożytkowi. Zastanówmy się choćby nad rolą Ellis Island wyspy położonej przy nowojorskim porcie. W ciągu ponad pięćdziesięciu lat przewinęły się przez nią miliony przyszłych Amerykanów. Pochodzili oni z najrozmaitszych, często ubogich części świata, zwykle nie znali angielskiego i należeli do różnych kulturowych tradycji. Jak to możliwe, 
W kolejnej części wywodu autorka dokładnie precyzuje cel metodycznych propozycji. Od tego momentu edukacja kulturowa, o której była mowa w pierwszym rozdziale, zostanie sprowadzona do szerokiego oglądu dziedzictwa polsko-żydowskiego na lekcjach polskiego. Badaczka, przywołując efektowną wypowiedź Łukasza Gawła, niejako czyni z niej cel nauczania o polsko-żydowskich relacjach:

Dziedzictwo kulturowe może być zarówno Świętym Graalem, jak i puszką Pandory. Służy budowaniu tożsamości, pomaga odnaleźć swoje miejsce w świecie, kreować kompetencje kulturowe. Może być najwyższą wartością. Staje się jednak groźne, jeśli służy do budowania poczucia wyższości nad innymi, daje przekonanie „bycia lepszym”. Miarą bezpieczeństwa w sferze dziedzictwa jest szacunek dla dziedzictwa innych, a jedyną akceptowaną postawę w tej mierze najłatwiej scharakteryzować słowami Antygony: Współkochać przyszłam, a nie wspótnienawidzić (s. 50) ${ }^{11}$.

Analiza kodu, jakim opisuje się Innego, jest według autorki kluczowym działaniem zmierzającym do zbadania i zrozumienia stereotypów związanych z postacią Żyda oraz kultury żydowskiej, tak bardzo odmiennej od polskiej. $\mathrm{W}$ tej części pracy czytelnik zetknie się z dobrze poprowadzonym wywodem na temat językowego obrazu Żydów - a w konsekwencji stereotypów na ich temat — popartym badaniami m.in. Kazimierza Ożoga, Jarosława Pacuły, Ireny Kamińskiej-Szmaj, Marcina Hernasa czy Michała Głowińskiego.

Zebrany materiał nie tylko uprawomocnia autorkę do zaproponowania konkretnych działań na lekcji polskiego, ale pozwala również na krytyczny ogląd już istniejących i stosowanych w szkole scenariuszy (lub czytanych tekstów) zaliczanych do niemal klasyki edukacji międzykulturowej. Najczęściej popełnianym błędem w tego typu publikacjach jest sprzeciw wobec stereotypowych przedstawień, którego efektem jest powołanie „nowego” stereotypu, paradoksalnie „alternatywnego” dla pierwszego. Według Kani takie zjawisko w niemal podręcznikowej formule można dostrzec w dobrze przyjętej przez szkołę książce Przemysława P. Grzybowskiego ${ }^{12}$.

że utworzyli oni jeden naród, który w dodatku łączy to, co określa się mianem »amerykańskiego snu«?". Zob. R. Pring: Edukacja w wielkokulturowym społeczeństwie. Tłum. K. Puławski. W: (Złudne) obietnice wielokulturowości. Red. J. Królikowska. Warszawa 2012, s. 180-181.

${ }^{11}$ Wypowiedź Łukasza Gawła pod hasłem „Dziedzictwo kulturowe jest dla mnie ważne, bo...” Cyt. za Kanią. Por. K. Zarzy cka: Rozgryźć dziedzictwo. Podręcznik dobrych praktyk upowszechniania dziedzictwa i edukacji o dziedzictwie kulturowym. Warszawa 2017, s. 224. Publikacja dostępna na: https://www.nid.pl/pl/Informacje_ogolne/Konkursy/MATERIA\%C5\%81Y\%20 EDUKACYJNE/Podrecznik\%20dobrych\%20praktyk_.pdf [data dostępu: 20.01.2018].

12 P.P. Grzybowski: Spotkania z Innymi. Czytanki do edukacji międzykulturowej. Ilustr. L. Fic. Kraków 2011. 
Badaczka, przywołując opowiadanie pt. Dawidek, analizuje sposób kreowania nowego wizerunku Żyda, którego jednak infantylna, uproszczona, a w konsekwencji nachalnie dydaktyczna konstrukcja, akcentująca jedynie wojenne dzieciństwo głównego bohatera, odmawiająca mu prawa do „zwykłych” doświadczeń spoza przestrzeni traumatycznej pamięci, jest nastawiona jedynie na efekt współczucia i litości. Tym samym ,czytanka” uniemożliwia młodemu odbiorcy utożsamienie się z jej bohaterem. Przyczyną tego odbiorczego rozdźwięku nie są przeżycia Dawida, których wyjątkowość musi wywoływać przecież uczucie obcości, ale przede wszystkim użyta w narracji topika Zagłady, która sprowadza opowieść do rzędu tekstów obliczonych na łatwe wzruszenie, paradoksalnie oddalające bohatera od czytelnika.

Dzięki temu spostrzeżeniu badaczka dotyka niezwykle istotnej kwestii, często zupełnie pomijanej w edukacji na temat Holokaustu, w której wzruszenie jest swoistym fetyszem pedagogiki przeszłości. Odkrycie przez czytelnika w postaci z przeszłości podobieństw do niego samego jest jedynie pierwszym etapem spotkania z Innym. Kolejny powinien intelektualizować to przeżycie, czyniąc $\mathrm{z}$ niego uniwersalną zasadę edukacji wielokulturowej. Rezygnacja z tego rodzaju uogólnień może, choć nie musi, prowadzić do estetyki kiczu, w której wzruszenie lub wzruszenie wywołane swym wzruszeniem ${ }^{13}$ sytuuje się w centrum zagadnień związanych z Holokaustem.

Aby uniknąć tego niepożądanego zjawiska stwarzającego bariery w kontakcie z Innym, Kania proponuje zadania: z jednej strony wykorzystujące naturalną ciekawość uczniów, z drugiej — zapobiegające nawiązywaniu dialogu wyłącznie w oparciu o trudne, traumatyzujące tematy. Jedną z takich propozycji jest sformułowanie przez uczniów pytań, nasuwających się im po lekturze hasła ,judaizm” zamieszczonego w encyklopedii szkolnej ${ }^{14}$. Oto niektóre z nich:

Jeśli ktoś jest chory i nie może obchodzić Waszego święta, co wtedy ma zrobić?; Czy spotkała Cię kiedyś dyskryminacja ze względu na to, że jesteś Żydem?; [...] Macie jakieś tradycyjne potrawy?; [...] W Polsce można kupić macę - ja ją lubię, a Ty? (s. 73-74).

Doświadczenia wyniesione z oglądu podręczników oraz metod, jakimi posługuje się edukacja międzykulturowa, prowadzą autorkę do ważnej konstatacji. Aby uniknąć efektu wzruszenia lub przesadnej intelektualizacji wspomnianych zagadnień, należałoby połączyć wysiłki polonisty, historyka, katechety, nauczy-

${ }_{13}$ Zob. P. Śpiewak: Kicz i estetyzacja polityki. W: S. Friedländer: Refleksy nazizmu. Esej o kiczu i śmierci. Tłum. M. Szu ster. Warszawa 2011, s. 9-23. Zob. również M. Wójcik-Dudek: Pamięć i zarządzanie przestrzenia. W: Eadem: W(y)czytać Zagładę. Praktyki postpamięci w polskiej literaturze XXI wieku dla dzieci i młodzieży. Katowice 2016, s. 251-257.

14 Język polski. Encyklopedia szkolna. Szkoła podstawowa, klasy IV_VI. Red. M. Tomczyk. Kraków 2006, s. 628-630. 
ciela wiedzy o kulturze oraz języka angielskiego (ewentualnie innego języka obcego). Taka współpraca dawałaby gwarancję merytorycznego oglądu problemu z zachowaniem należnych mu proporcji. Nie należy przy tym zapominać, że istotnym wsparciem działań szkoły mogą być różne formy edukacji pozalekcyjnej. Badaczka zachęca do korzystania z oferty warsztatów prowadzonych przez muzea czy instytucje powołane w celu przybliżania szkole fenomenu edukacji międzykulturowej (np. Szkoła Dialogu). Formy pracy stosowane w tych przestrzeniach, interesujący materiał przygotowany przez specjalistów z wielu dziedzin sprawiają, że edukacja międzykulturowa ma wymiar interdyscyplinarny, co skutecznie chroni ją przed zakusami jednostronnego i w konsekwencji zubażającego wykorzystywania jej obecności w szkole. To wystarczający powód, aby przemyśleć formę nauczania o Zagładzie i sprawić, by uczniowie w XXI wieku odczuwali nie tylko potrzebę edukacji na jej temat, ale również niezwykłą rolę, jaką odgrywa w poznawaniu zarówno przeszłości, jak i w rozumieniu współczesnego świata. Temu zagadnieniu badaczka poświęca najobszerniejszy rozdział książki zatytułowany Holokaust a edukacja na miarę XXI wieku.

Otwiera go przegląd stanu badań na temat Zagłady w polskiej szkole. Czytelnik dostaje pewnego rodzaju listę najważniejszych publikacji z tego zakresu, która z pewnością odpowiada potrzebom nauczycieli poszukujących ważnych tekstów niezbędnych do przygotowania interesujących oraz merytorycznie poprawnych zajęć. Badaczka słusznie zauważa, że memory boom, dokonujący się $\mathrm{w}$ wielu dyscyplinach naukowych, niespecjalnie znajduje przełożenie na dyskurs szkolny. Analiza podstawy programowej z języka polskiego do ośmioklasowej szkoły podstawowej wykazuje bowiem brak zainteresowania tekstami dotyczącymi Zagłady ${ }^{15}$. Ta część książki Kani wpisuje badania autorki w szerszy kontekst uruchomiony przez znakomitą publikację Sylwii Karolak Doświadczenie Zagłady w literaturze polskiej 1947-1991. Kanon, który nie powstat ${ }^{16}$.

Istniejącą lukę badaczka próbuje wypełnić zajęciami praktycznymi zainspirowanymi strategią nauczania zaproponowaną przez Karen Shawn podczas seminarium „Max M. Kaplan Summer Institute for Educators” w Muzeum Holokaustu w Houston w Stanach Zjednoczonych w 2013 roku. Zajęcia zostały opisane w tekście Shawn Ogniska pogladów, przetłumaczonym przez Mariannę Szumal i adaptowanym przez Kanię. Materiał znalazł się w Aneksie Lekcji

${ }^{15} \mathrm{Z}$ oczywistych względów autorka nie mogła włączyć do swej refleksji zapisów podstawy programowej dla szkół średnich. Kiedy książka została opublikowana, wciąż trwały prace nad tym dokumentem.

16 S. Karolak: Doświadczenie Zagłady w literaturze polskiej 1947-1991. Kanon, który nie powstat. Poznań 2014. Zob. recenzję: M. Wójcik-Dudek: Sylwia Karolak: Doświadczenie Zagłady w literaturze polskiej 1947-1991. Kanon, który nie powstat. Poznań 2014. W: „Z Teorii i Praktyki Dydaktycznej Języka Polskiego". T. 24. Red. D. Krzyżyk. Katowice 2015, s. $113-117$. 
(nie)obecności... ${ }^{17}$ (s. 179-185). Badaczka, nie tracąc zmysłu krytycznego, dostrzega w metodach stosowanych przez Shawn pewnego rodzaju „koloryt lokalny" edukacji o Zagładzie, który wydaje się naturalny dla amerykańskich uczestników seminarium. Aby jednak propozycje autorki Ogniska pogladów mogły bez zastrzeżeń przyjąć się w polskiej szkole, należy uwzględnić specyfikę Holokaustu, który wydarzył się na ziemiach polskich oraz pracować na tekstach, które funkcjonują w rodzimym, ale nie tylko szkolnym obiegu.

Badaczka, dostrzegając dotychczasową nieprzystawalność działań dydaktycznych do interpretowanych opowiadań Idy Fink ${ }^{18}$, postuluje zmianę metodycznego paradygmatu i zgodnie z zaleceniami Shawn proponuje uczniom ${ }^{19}$ metodę silent conversation (rozmowa w milczeniu). Polega ona na wysłuchaniu lub przeczytaniu jednego z opowiadań (np. Zabawa w klucz; Aryjskie papiery) oraz zadaniu autorce pytań formułowanych przez uczniów, którzy wcześniej poznali jej biografię. Uczestnicy na dużych arkuszach papieru zawieszonych na ścianach zapisują propozycje pytań:

Co dla Pani jest teraz najważniejsze?; [...] Czy da się po tym żyć?; Czy to było Pani dziecko, czy to Pani była tym dzieckiem?; Czy mówienie/pisanie o tych przeżyciach pomaga? (s. 117).

Pytania mają trzy podstawowe funkcje. Po pierwsze, zbierają niejako materiał, który stanowi punkt wyjścia do refleksji nad przeszłością. Po drugie, skłaniają do namysłu nad nazywaniem własnych uczuć wobec wstrząsających przeżyć, co może stanowić wstęp do dyskusji nad np. koncepcją niewyrażalności Zagłady. W końcu, po trzecie, pozwalają na działania interpretacyjne będące formą samodzielnego myślenia, wszak uczniowie, wyzwoliwszy się z pseudoheurezy nieudolnie udającej metodę majeutyczną, bez skrępowania mogą zadawać tekstowi pytania. To właśnie pytanie sytuuje się w centrum metody opisywanej przez Kanię. Jego autorem może być również nauczyciel, który dzięki mądrym i empatycznym zapytaniom nie tylko otwiera na tekst, ale przede wszystkim stwarza swym uczniom szansę na zintelektualizowaną refleksję za-

17 Aneks stanowi integralną część głównego wywodu. Oprócz wspomnianych już Ognisk poglądów. O paleniu książek przez nazistów w 1933 roku Karen Shawn, zamieszczono w nim komentarz metodyczny tego tekstu autorstwa Marianny Szumal oraz „, To wszystko jest antysemicka legenda...”. Przełamujac stereotyp Żyda Małgorzaty Kulik oraz Klaudii Muchy — sprawozdanie z lekcji poświęconej filmowi Ziarno prawdy Borysa Lankosza, będącemu ekranizacją powieści Zygmunta Miłoszewskiego o tym samym tytule.

${ }_{18} \mathrm{~W}$ tym miejscu warto odwołać się do badań nad odbiorem opowiadań Idy Fink. Zob. A. Kasperek: Opowiadania Idy Fink - nowość na lekcjach języka polskiego w gimnazjum. W: Auschwitz i Holokaust. Dylematy i wyzwania polskiej edukacji. Red. P. Trojański. Oświęcim 2012, s. 101-110.

19 Zajęcia były przeprowadzane również dla studentów polonistyki oraz grupy nauczycieli. 
wsze zakotwiczoną jednak w prywatnym oraz indywidualnym przeżyciu utworu. Oto przykłady pytań „otwierających”:

Co czułaś/czułeś, czytając Aryjskie papiery?; O co zapytałabyś/zapytałbyś bohaterkę Aryjskich papierów?; Czy za uratowanie życia warto zapłacić każdą cenę?; Czy mężczyzna — bohater Aryjskich papierów — powinien otrzymać tytuł Sprawiedliwy wśród Narodów Świata? (s. 125-130).

Należy podkreślić, że autorka, według mnie bardzo słusznie, dystansuje się od dramy, która w przypadku lekcji na temat Zagłady, wydaje się z jednej strony zbyt traumatyzująca, z drugiej zaś — banalizująca Wydarzenie. Proponuje jednak ciekawe paradramowe ćwiczenia odnoszące się do znanego filmu Pepe Danquarta Biegnij, chtopcze, biegnij. Badaczka, mimo zastrzeżeń pod adresem artystycznego wymiaru filmu, dostrzega w nim potencjał emocjonalny, który z powodzeniem można wykorzystać na lekcji. Przed projekcją uczniowie losują karteczki z zaznaczonym „punktem widzenia”, który muszą przyjąć podczas emisji filmu, np.:

Jesteś ortodoksyjnym wyznawcą judaizmu. Wszelkie odstępstwa od religijnych nakazów uważasz za zdradę. Jak ocenisz to, co spotkało bohatera? Czy jemu albo twórcom filmu postawisz jakieś zarzuty?; [...] Jesteś ,„przeciętnym Kowalskim”. Nie interesujesz się historią, mało wiesz o II wojnie światowej. Co w historii pokazanej w filmie bardzo Cię dziwi? Co odkrywasz ze zdumieniem? Jakie wnioski dla siebie wyciągniesz? (s. 134).

Po obejrzeniu filmu uczniowie zapisują również „swoje” indywidualne wnioski bez wchodzenia we wcześniejsze role, np.:

Jesteś sobą. Jakie są Twoje spostrzeżenia, uwagi do podjętej w filmie tematyki i sposobu jej przedstawienia? Coś Ci się w tym filmie spodobało? Coś Cię zaskoczyło? Coś Ci się nie podoba? (s. 135).

Autorka przekonuje, że taka procedura czytania filmu o Zagładzie uświadamia uczniom istnienie oraz działanie pewnych klisz kulturowych, mających niebagatelny wpływ na ocenę wydarzenia/sytuacji. Zmienność punktów widzenia generuje sensy otwierające na nowe paradygmaty myślenia.

Powyższy wniosek pozwala badaczce na przeniesienie eksperymentu na nieco inny, bardziej współczesny obszar. Interesuje ją, w jaki sposób uczniowie reagują na zjawisko łączenia symboli Zagłady z niechęcią do migrantów przybywających do Europy. W tym celu korzysta $\mathrm{z}$ memu przedstawiającego bramę z napisem Arbeit macht frei, pod którą umieszczono hasło „Polska jest 
gotowa na przyjęcie imigrantów". Opinie wśród uczniów są podzielone, ponieważ w grupie znalazły się osoby popierające hasło, jak i wyrażające wobec niego ostry sprzeciw. Eksperyment pokazał, że Zagłada bywa sprowadzona do obrazu (narzędzia), który poddawany manipulacji może służyć paradoksalnie nie budowaniu wspólnoty, ale wspieraniu istniejących bądź tworzeniu nowych podziałów.

W zakończeniu tego rozdziału czuje się ostrożność autorki w wyciąganiu daleko idących wniosków. Szczery charakter finału dowodzi, że entuzjazm, z jakim referuje sprawdzoną przez siebie oraz częściowo współtworzoną koncepcję edukacji międzykulturowej, nie jest w stanie zawiesić jej krytycznego oglądu, niezbędnego przecież w opisie naukowym. Choć z satysfakcją podkreśla, że uczniowie, którzy wcześniej uczestniczyli w projekcie „Małopolska pamięta”, poznali żydowską historię Oświęcimia, zwiedzali Auschwitz-Birkenau oraz wzięli udział $\mathrm{w}$ warsztatach antydyskryminacyjnych, protestowali przeciwko wspomnianemu hasłu, to jednak zaznacza, że edukacja uwzględniająca istnienie Innego musi odbywać się nieustannie, ponieważ „bakcyl dżumy nigdy nie umiera" (s. 139), oraz mieć charakter poszukujący, uwzględniający zmianę kontekstu historycznego czy obyczajowego, w którym zanurzony jest młody człowiek. Wydaje się więc, i do tego przekonuje badaczka, że jedynie niedomknięta formuła pedagogiki Innego pozwala na autentyczne otwarcie na dialog.

Ostatni rozdział pracy Problemy polskiej pamięci zbiorowej dopełnia interesującą propozycję edukacji międzykulturowej, choć ta część książki, obudowana bogatą literaturą przedmiotową, wydaje się najmniej metodyczna. Autorka, prezentując najważniejsze opracowania dotyczące relacji polsko-żydowskich (m.in. My z Jedwabnego Anny Bikont) oraz polityki i kultury pamięci (m.in. Martin Pollack, Aleida Assman, Przemysław Czapliński, Jean-Yves Potel, Jan Tomasz Gross, publikacje: Ślady Holokaustu w imaginarium kultury polskiej oraz Pamięć Shoah. Kulturowe reprezentacje i praktyki upamiętniania), przekonuje, że lista lektur holokaustowych powinna poszerzyć się o najnowsze teksty literackie podejmujące problem polsko-żydowskiego dziedzictwa.

Pomysł, aby uczniowie czytali Rejwach Mikołaja Grynberga czy Fatszerzy pieprzu Moniki Sznajderman, wydaje się znakomity, nie tylko dlatego, że jest to literatura najwyższych lotów, ale również dlatego, że teksty te świetnie nadają się do przepracowania traum, których ciągła obecność nie pozwala na wykonanie kroku w przyszłość. Problem polega jednak na tym, że autorka nie udziela wskazówek dotyczących trybu lektury zaproponowanych książek. Czytelnik do tej pory prowadzony przez autorkę niemal ,za rękę”, m.in. dzięki klarownie skonstruowanemu wykładowi, wyposażany w konkretne pomysły metodyczne, teraz styka się z ledwie zarysowaną propozycją uzupełnienia listy lektur na temat Zagłady. Mimo pewnego niedosytu nietrudno jest mu się zgodzić na postulat włączenia „nowych” utworów, dających szansę na stawianie pytań, w których wyrażałaby się wrażliwość oraz wiedza współczesnych. 
Uważam jednak, że słabe zasygnalizowanie tego problemu jest przemyślanym chwytem, zręcznie kierującym czytelnika ku finałowi książki, zawierającym się w tytule ostatniego rozdziału - Podsumowanie, czyli lekcja (nie) do odrobienia?. W takim kontekście propozycja „nowych” tytułów, jednak bez wskazówek metodycznych, ma przekonywać, że o lekcjach z Zagłady nigdy nie będzie można powiedzieć, że stanowią dokończony projekt. Stając się wyzwaniem dla szkoły, wymuszając ciągły ruch myśli, nakaz nieprzyzwyczajania się i ciągłej gotowości do przemyślenia relacji ja - Inny, wskazują kierunek edukacji międzykulturowej, która w obliczu zmian migracyjnych, pomimo różnic, może tworzyć alfabet porozumienia.

Książka Kani Lekcja (nie)obecności... stanowi rzadkie, jeśli dotąd nie jedyne, tak kompletne opracowanie wątku dziedzictwa polsko-żydowskiego w edukacji polonistycznej ${ }^{20}$. Autorka w fascynujący sposób łączy badania nad interesującym ją tematem z konkretnymi rozwiązaniami metodycznymi, które jak to niestety często bywa, mogą banalizować prezentowane zagadnienia. W przypadku lekcji zaproponowanych przez Kanię niebezpieczeństwo trywializacji Zagłady nie tylko zostało oddalone, ale dodatkowo dzięki przesunięciu akcentów Holokaust stał się pretekstem do refleksji nad stosunkiem do Innego w ,płynnej ponowoczesności”, nie tracąc niczego z przypisywanej mu formuły bezprecedensowości ${ }^{21}$. To, że autorka poradziła sobie z tym trudnym zadaniem, dodatkowo włączając je w dyskurs edukacji polonistycznej, z pewnością zasługuje na uwagę studentów (nie tylko) polonistyki, nauczycieli oraz wszystkich, którzy w edukacji międzykulturowej widzą szansę dla dialogu.

\section{Bibliografia}

Bauman Z.: O tarapatach tożsamości w ciasnym świecie. W: Dylematy wielokulturowości. Red. W. Kalaga. Kraków 2004.

Bikont A.: My z Jedwabnego. Warszawa 2004.

Boroń A.: Holokaust i jego reprezentacje w przestrzeni pamięci i tożsamości. W: Eadem: Pedagogika (p)o Holocauście. Pamięć. Tożsamość. Edukacja. Poznań 2013.

Borows ki A.: Tożsamość polska i wielokulturowość jako problem edukacji polonistycznej. W: Polonistyka w przebudowie. T. 2. Red. M. Czermińska, S. Gajda, K. Kłosiński et al. Kraków 2005.

${ }^{20}$ Mam tu na myśli jedynie obszar edukacji polonistycznej, wspieranej klasyczną już publikacją z zakresu nauk społecznych autorstwa Roberta Szuchty i Piotra Trojańskiego. Zob. R. Szuchta, P. Trojański: Zrozumieć Holokaust. Książka pomocnicza do nauczania o zagładzie Żydów. Warszawa 2012.

${ }^{21}$ Por. B. Lang: Przedstawienie zła: etyczna treść a literacka forma. Tłum. A. Ziębińska-Witek. „Literatura na Świecie” 2004, nr 1/2, s. 15-63. 
Fink I.: Wiosna 1941. Warszawa 2011.

Gromadzka B.: Edukacja polonistyczna w kontekście dylematów kulturowych. W: Edukacja. Migracja. Edukacja międzykulturowa w kontekście kryzysu migracyjnego z perspektywy krajów V4. Red. E. Kledzik, M. Praczyk. Poznań 2016.

Grynberg M.: Rejwach. Warszawa 2017.

Grzybowski P.P.: Spotkania z Innymi. Czytanki do edukacji międzykulturowej. Ilustr. L. Fic. Kraków 2011.

Hirsch M.: Family Frames: Photography, Narrative and Postmemory. Cambridge 2000.

Język polski. Encyklopedia szkolna. Szkoła podstawowa, klasy IV_VI. Red. M. Tomczyk. Kraków 2006.

Kania A.: Lekcja (nie)obecności. Dziedzictwo polsko-żydowskie w edukacji polonistycznej. Kraków 2017.

Kania A.: „Polak młody” na lekcjach języka polskiego. Edukacja polonistyczna a ksztattowanie poczucia tożsamości narodowej. Kraków 2015.

Karolak S.: Doświadczenie Zagłady w literaturze polskiej 1947-1991. Kanon, który nie powstat. Poznań 2014.

Kasperek A.: Opowiadania Idy Fink - nowość na lekcjach języka polskiego w gimnazjum. W: Auschwitz i Holokaust. Dylematy i wyzwania polskiej edukacji. Red. P. Trojański. Oświę$\operatorname{cim} 2012$.

Kunce A.: Zlokalizować tożsamość!. W: Dylematy wielokulturowości. Red. W. Kalaga. Kraków 2004.

Lang B.: Przedstawienie zła: etyczna treść a literacka forma. Tłum. A. Ziębińska-Witek. „Literatura na Świecie" 2004, nr 1/2.

Pakier M.: „, Postmemory” jako figura w popularnym dyskursie o Zagładzie. „Kwartalnik Historii Żydów" 2005, nr 2.

Pamięć Shoah. Kulturowa reprezentacja i praktyki upamiętniania. Red. T. Majewski, A. Zeidler- Janiszewska. Łódź 2011.

Pring R.: Edukacja w wielkokulturowym społeczeństwie. Tłum. K. Puławski. W: (Złudne) obietnice wielokulturowości. Red. J. Królikowska. Warszawa 2012.

Sznajderman M.: Fatszerze pieprzu. Historia rodzinna. Wołowiec 2016.

Szuchta R.: Refleksje o nauczaniu historii Holokaustu w polskiej szkole. W: Tematy żydowskie. Red. E. Traba, R. Traba. Olsztyn 1999.

Szuchta R., Trojański P.: Zrozumieć Holokaust. Książa pomocnicza do nauczania o zagładzie Żydów. Warszawa 2012.

Ślady Holokaustu w imaginarium kultury polskiej. Red. J. Kowalska-Leder, P. Dobrosielski, I. Kurz, M. Szpakowska. Warszawa 2017.

Śliwerski B.: Wspótczesne teorie i nurty wychowania. Kraków 2010.

Śpiewak P.: Kicz i estetyzacja polityki. W: S. Friedländer: Refleksy nazizmu. Esej o kiczu i śmierci. Tłum. M. Szuster. Warszawa 2011.

Wójcik-Dudek M.: Pamięć i zarządzanie przestrzenią. W: Eadem: W(y)czytać Zagładę. Praktyki postpamięci w polskiej literaturze XXI wieku dla dzieci i młodzieży. Katowice 2016.

Wójcik-Dudek M.: Sylwia Karolak: Doświadczenie Zagłady w literaturze polskiej 1947-1991. Kanon, który nie powstat. Poznań 2014. W: „Z Teorii i Praktyki Dydaktycznej Języka Polskiego”. T. 24. Red. D. Krzyżyk. Katowice 2015. 
334 Artykuły recenzyjne

\section{Źródła internetowe}

Zarzycka K.: Rozgryźć dziedzictwo. Podręcznik dobrych praktyk upowszechniania dziedzictwa $i$ edukacji o dziedzictwie kulturowym. https://www.nid.pl/pl/Informacje_ogolne/Konkursy/ MATERIA\%C5\%81Y\%20EDUKACYJNE/Podrecznik\%20dobrych\%20praktyk_pdf. 